\title{
Correlation Between Use of The Contraception and Exclusive Breastfeeding In Indonesia in 2017 (2017 IDHS Analysis Data)
}

\author{
Febrianti Prasmono Putri ${ }^{1}$, Septa Katmawanti' ${ }^{1}$ Erianto Fanani ${ }^{1}$ \\ ${ }^{1}$ Faculty of Sports Science, State University of Malang, Indonesia
}

\begin{abstract}
Breast milk is the first need for a newborn baby. Infants aged 0 to 6 months who are breastfed without any other food define exclusive breastfeeding. Exclusive breastfeeding can be influenced by several factors, one of which is contraception. Inappropriate use of contraception can affect exclusive breastfeeding. This study aimed to determine the correlation between contraceptive use and exclusive breastfeeding in Indonesia in 2017. The research design in this study was descriptive-analytic with a cross-sectional approach. This study examines the population of WUS (Women of Childbearing Age) who are married and have their last child aged 0-6 months with a total sample of 1891 people, with a sampling technique using total sampling. The data was taken from the results of the 2017 Indonesian Health Demographic Survey (IDHS). The data analysis of this study used the Chi-Square Statistical Test. The results of data analysis showed that $53 \%$ of WUS (Women of Childbearing Age) used contraception, and $47 \%$ of WUS (Women of Childbearing Age) did not use contraception. Meanwhile, $46 \%$ of WUS (Women of Childbearing Age) gave exclusive breastfeeding, and 54\% of WUS (Women of Childbearing Age) did not give exclusive breastfeeding. The Chi-Square test results showed a p-value of $0.000(p<0.05)$, which means there is a correlation between contraceptive use and exclusive breastfeeding in Indonesia.
\end{abstract}

Keywords: Contraception, Exclusive Breastfeeding, Women of Childbearing Age

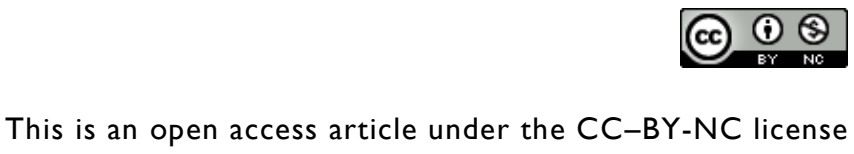

\section{INTRODUCTION}

The first need needed by a newborn baby is breast milk given by the mother. Exclusive breastfeeding is recommended for infants up to 6 months of age without any other food. After six months, the baby is given additional food, and breastfeeding is also continued until the child is two years old.[8] Tama et al. (2016) stated that 2 out of 5 newborns in Indonesia did not get early breastfeeding initiation.[32] Without exclusive breastfeeding, infants become more susceptible to disease and increase the risk of infant death.[25] Based on data in 2019, the condition with the most significant contributor to death in children aged 29 days - 11 months was infectious. Pneumonia and diarrhea are still the main problems that have caused 979 deaths due to pneumonia and 746 deaths due to diarrhea. Meanwhile, based on 2018 data, $17.1 \%$ of toddlers aged 0-23 months were stunted, and $12.8 \%$ were very short toddlers. This percentage increased by $13.2 \%$ for short toddlers and $6.9 \%$ for very short toddlers from the previous year.[13] One of the factors that cause pneumonia, diarrhea, and high stunting in Indonesia is non-exclusive breastfeeding.[1]; [30]; [31] Breast milk can protect infants from diarrheal diseases, pneumonia, stunting, and reduce the risk of obesity in children and also reduce the risk of chronic diseases.[33]

Corresponding author

Septa Katmawanti, septakatma.fik@um.ac.id

DOI: (to be processed)

Research Synergy Foundation 
RSF Conference Series: Medical and Health Science, Vol. 1 (1), 42-52

Correlation Between Use Of The Contraception And Exclusive Breastfeeding In Indonesia In 2017 (2017 IDHS

Analysis Data)

Febrianti Prasmono Putri, Septa Katmawanti, Erianto Fanani

World Breastfeeding Week in 2012 stated that of all babies in the world, only 32.6\% of a total of 136.7 million babies received exclusive breastfeeding at the age of 0-6 months. This can illustrate that the coverage of exclusive breastfeeding is still less than $80 \%$ due to the lack of mothers who give exclusive breastfeeding to babies.[16] $41 \%$ of babies worldwide who are exclusively breastfed are infants less than six months old. This figure is far from the world target in 2030, which is $70 \%$ of babies get exclusive breastfeeding. Meanwhile, the percentage of mothers who breastfeed their babies from one year to two has decreased to $45 \%$. The WHO target in 2030 is that $80 \%$ of infants worldwide aged 0 to one year are exclusively breastfed, and $60 \%$ of infants worldwide aged 0 to two years are exclusively breastfeeding.[33] Based on data from the World Breastfeeding Trend Initiative in 2012, Indonesia is ranked 49th out of 51 countries in the Exclusive Breastfeeding category.[35]

The percentage of infants aged 0 to 6 months in Indonesia who received exclusive breastfeeding in 2015 was 55.7\%.[9] In 2016, the rate of infants aged 0 to 6 months who received exclusive breastfeeding was 54\%.[10] In 2017, the rate of infants aged 0 to 6 months who were exclusively breastfed was $61.33 \%$, and in 2018 infants who exclusively breastfed were 68.74\%.[11],[12] Meanwhile, in 2019, babies aged 0 up to 6 months who received exclusive breastfeeding were 67.74\%.[13] There was an increase from 2016 to 2017, including in 2017 to 2018, although the increase was not too significant. However, there was a decline from 2015 to 2016, including 2018 to 2019. From 2015 to 2019, the coverage of exclusive breastfeeding for infants aged 0-6 months in Indonesia still did not meet the strategic plan target, namely the coverage percentage of $69 \%$.[14 ]

Two factors can affect exclusive breastfeeding: maternal factors consisting of knowledge, psychology, education, contraception, and breast anatomy.[19],[23] The next influencing factor is environmental factors which consist of support. husband, and support from health workers.[28] Based on these factors, one of the factors that can affect exclusive breastfeeding is contraceptive use $(\mathrm{OR}=10,500)$.[4] Several studies have stated a correlation between the use of contraception with a decrease in the volume and duration of breast milk which affects the adequacy of exclusive breastfeeding.[3],[36]

This study uses data obtained from the 2017 IDHS (Indonesian Health Demographic Survey). have children aged 0 to 6 months. This study also examines contraception without separating by type of contraception. This has not been found in previous studies. Based on this explanation, researchers are interested in exploring the correlation between contraception and exclusive breastfeeding in Indonesia through research. 


\section{LITERATURE REVIEW}

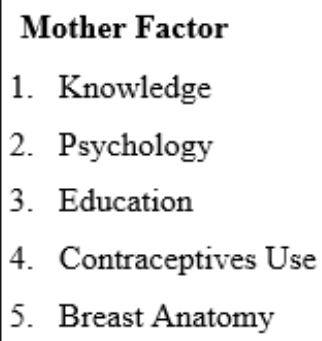

Environmental factor

1. Husband's Support

2. Health Officer Support

Figure 1. Theoretical Framework

\section{RESEARCH METHODOLOGY}

The research design in this study used descriptive-analytic with a cross-sectional approach. This study used secondary data taken from data from the 2017 IDHS (Indonesian Health Demographic Survey). The population in this study were all WUS (Women of Childbearing Age) who were married and had their last child aged 0 to 6 months. The number of samples in this study was 1,891 WUS (Women of Childbearing Age) obtained using the total sampling technique. The data analysis of this research used univariate and bivariate analysis. Univariate analysis was conducted to determine the distribution of frequency and percentage by performing descriptive statistical tests. Meanwhile, the bivariate analysis uses the ChiSquare Statistical Test, which determines the correlation and the magnitude of the influence between variables.

\section{FINDINGS AND DISCUSSION}

\section{Results}

Univariate Analysis

Age

The following is a description of the characteristics of the respondents in this study based on age with classification based on the 2017 IDHS.

Table 1. Frequency Distribution of Respondents Age

\begin{tabular}{ccc}
\hline Age & Frequency & Percentage (\%) \\
\hline $15-19$ & 128 & 6,8 \\
$20-24$ & 386 & 20,4 \\
$25-29$ & 528 & 27,9 \\
$30-34$ & 472 & 25
\end{tabular}


RSF Conference Series: Medical and Health Science, Vol. 1 (1), 42-52

Correlation Between Use Of The Contraception And Exclusive Breastfeeding In Indonesia In 2017 (2017 IDHS Analysis Data)

Febrianti Prasmono Putri, Septa Katmawanti, Erianto Fanani

\begin{tabular}{ccc}
\hline Age & Frequency & Percentage (\%) \\
\hline $35-39$ & 282 & 14,9 \\
$40-44$ & 87 & 4,6 \\
$45-49$ & 8 & 0,4 \\
\hline Total & $\mathbf{1 8 9 1}$ & $\mathbf{1 0 0 \%}$
\end{tabular}

The table above shows that most respondents were aged 25-29 years, namely 528 people (27.9\%).

Province

The following describes this study's respondents' characteristics based on the province of residence with the local classification based on the 2017 IDHS.

Table 2. Frequency Distribution of Respondent Provinces

\begin{tabular}{ccc}
\hline Province & Frequency & Percentage (\%) \\
\hline North Sumatra & 111 & 5,9 \\
Aceh & 118 & 6,2 \\
Riau & 39 & 2,1 \\
West Sumatra & 45 & 2,4 \\
Jambi & 28 & 1,5 \\
South Sumatra & 44 & 2,3 \\
Bengkulu & 27 & 1,4 \\
Lampung & 42 & 2,2 \\
Bangka Belitung & 29 & 1,5 \\
Riau islands & 31 & 1,6 \\
Jakarta & 49 & 2,6 \\
West Java & 173 & 9,1 \\
Central Java & 115 & 6,1 \\
Yogyakarta & 14 & 0,7 \\
East Java & 115 & 6,1 \\
Banten & 64 & 3,4 \\
Bali & 22 & 1,2 \\
East Nusa Tenggara & 114 & 6 \\
West Nusa Tenggara & 49 & 2,6 \\
South Kalimantan & 23 & 1,2 \\
East Kalimantan & 40 & 2,1 \\
Central Kalimantan & 21 & 1,1 \\
North Kalimantan & 34 & 1,8 \\
West Kalimantan & 42 & 2,2 \\
North Sulawesi & 10 & 0,5 \\
\hline
\end{tabular}


RSF Conference Series: Medical and Health Science, Vol. 1 (1), 42-52

Correlation Between Use Of The Contraception And Exclusive Breastfeeding In Indonesia In 2017 (2017 IDHS

Analysis Data)

Febrianti Prasmono Putri, Septa Katmawanti, Erianto Fanani

\begin{tabular}{ccc}
\hline Province & Frequency & Percentage (\%) \\
\hline South Sulawesi & 70 & 3,7 \\
Central Sulawesi & 57 & 3 \\
Gorontalo & 20 & 1,1 \\
Southeast Sulawesi & 84 & 4,4 \\
West Sulawesi & 64 & 3,4 \\
Maluku & 95 & 5 \\
North Maluku & 45 & 2,4 \\
West Papua & 22 & 1,2 \\
Papua & 35 & 1,9 \\
\hline Total & $\mathbf{1 8 9 1}$ & $\mathbf{1 0 0 \%}$
\end{tabular}

The table above shows that most of the respondents live in the province of West Java, namely 173 people (9.1\%).

Lastest education

The following describes the characteristics of respondents in this study based on their latest education with the classification based on the 2017 IDHS.

Table 3. Frequency Distribution of Respondents' Last Education

\begin{tabular}{ccc}
\hline Last Education & Frequency & Percentage (\%) \\
\hline No Education & 26 & 1,4 \\
Primary school & 439 & 23,2 \\
Secondary school & 1057 & 55,9 \\
Higher & 369 & 19,5 \\
\hline Total & $\mathbf{1 8 9 1}$ & $\mathbf{1 0 0 \%}$
\end{tabular}

The table above shows that most of the respondents have the last education of secondary school, which is 1057 people (55.9\%).

Baby's Age

The following is a description of the characteristics of the respondents in this study based on the baby's age with the classification of the baby's age based on the 2017 IDHS.

Table 4. Frequency Distribution of Respondents' Infant Age

\begin{tabular}{ccc}
\hline Age (month) & Frequency & Percentage (\%) \\
\hline 0 & 119 & 6,3 \\
1 & 296 & 15,7 \\
2 & 295 & 15,6 \\
3 & 310 & 16,4
\end{tabular}


RSF Conference Series: Medical and Health Science, Vol. 1 (1), 42-52

Correlation Between Use Of The Contraception And Exclusive Breastfeeding In Indonesia In 2017 (2017 IDHS

Analysis Data)

Febrianti Prasmono Putri, Septa Katmawanti, Erianto Fanani

\begin{tabular}{ccc}
4 & 320 & 16,9 \\
5 & 293 & 15,5 \\
6 & 258 & 13,6 \\
\hline Total & $\mathbf{1 8 9 1}$ & $\mathbf{1 0 0 \%}$ \\
\hline
\end{tabular}

The table above shows that most of the respondents' babies were four months old, i.e., 320 babies $(16.9 \%)$.

Contraception Types

The following describes the characteristics of respondents in this study based on the type of contraception used by respondents with the classification of contraception types based on Rofikoh et al. (2019).

Table 5. Frequency Distribution of Respondents' Contraception Types

\begin{tabular}{ccc}
\hline Contraception Types & Frequency & Percentage (\%) \\
\hline Hormonal Contraception & 740 & 74 \\
Non-hormonal contraception & 263 & 26 \\
\hline Total & $\mathbf{1 0 0 3}$ & $\mathbf{1 0 0 \%}$ \\
\hline
\end{tabular}

The table above shows that the type of contraception used by respondents is hormonal contraception, 740 people or $74 \%$ of the 1003 respondents who use contraception.

Contraception Methods

The following describes the characteristics of respondents in this study based on the contraception methods used by respondents with the classification of contraception methods based on the 2017 IDHS.

Table 6. Frequency Distribution of Respondents' Contraception Methods

\begin{tabular}{ccc}
\hline Contraception Methods & Frequency & Percentage (\%) \\
\hline Pill & 85 & 8 \\
IUD & 37 & 4 \\
Injection & 605 & 60 \\
Male Condom & 42 & 4 \\
Female Sterilization & 78 & 8 \\
Periodic Abstinence/Calendar & 18 & 2 \\
Withdrawal & 57 & 6 \\
Other Traditional Methods & 4 & 0 \\
Implant & 50 & 5 \\
Lactational Amenorrhea Method & 26 & 3 \\
Other Modern Methods & 1 & 0 \\
\hline Total & $\mathbf{1 0 0 3}$ & $\mathbf{1 0 0} \%$
\end{tabular}


The table above shows that most respondents used contraception, namely 605 people or $60 \%$ of the 1003 respondents.

Contraception Use

The following is the description of contraception use in the respondents of this study with the classification of contraception use based on the 2017 IDHS.

Table 7. Distribution of Frequency of Use of Contraception

\begin{tabular}{ccc}
\hline Contraception Use & Frequency & Percentage (\%) \\
\hline Using Contraception & 1003 & 53 \\
Not Using Contraception & 888 & 47 \\
\hline Total & $\mathbf{1 8 9 1}$ & $\mathbf{1 0 0 \%}$ \\
\hline
\end{tabular}

The table above shows that many respondents use family planning, namely 1003 people (53\%). Meanwhile, respondents who did not use family planning were 888 people (47\%).

Exclusive Breastfeeding

The description of exclusive breastfeeding in the respondents of this study can be described in the following table of the frequency distribution of exclusive breastfeeding. Classification of exclusive breastfeeding based on Erlani et al. (2020).

Table 8. Distribution of Exclusive Breastfeeding Frequency

\begin{tabular}{ccc}
\hline Exclusive Breastfeeding & Frequency & Percentage (\%) \\
\hline Exclusive breastfeeding & 870 & 46 \\
Non-Exclusive Breastfeeding & 1021 & 54 \\
\hline Total & $\mathbf{1 8 9 1}$ & $\mathbf{1 0 0 \%}$ \\
\hline
\end{tabular}

The table above shows that most respondents who did not give exclusive breastfeeding to their babies were 1021 people (54\%). Meanwhile, a total of 870 people (46\%) of respondents gave exclusive breastfeeding to their babies.

\section{Bivariate Analysis}

Bivariate analysis in this study analyzes the dependent variable, namely exclusive breastfeeding, with the independent variable, namely contraceptive use. The following are the results of the bivariate analysis in this study.

Table 9. Correlation Between Contraceptive Use and Exclusive Breastfeeding

\begin{tabular}{cccccccc}
\hline \multirow{3}{*}{ Contraception Use } & \multicolumn{2}{c}{ Exclusive Breastfeeding } & & & & \\
\cline { 2 - 4 } & $\begin{array}{c}\text { Exclusive } \\
\text { breastfeeding }\end{array}$ & $\begin{array}{l}\text { Non-Exclusive } \\
\text { Breastfeeding }\end{array}$ & N & OR & p-value \\
\cline { 2 - 7 } & $\mathrm{n}$ & $\%$ & $\mathrm{n}$ & & & & \\
\hline
\end{tabular}


RSF Conference Series: Medical and Health Science, Vol. 1 (1), 42-52

Correlation Between Use Of The Contraception And Exclusive Breastfeeding In Indonesia In 2017 (2017 IDHS

Analysis Data)

Febrianti Prasmono Putri, Septa Katmawanti, Erianto Fanani

\begin{tabular}{ccccccccc}
\hline $\begin{array}{c}\text { Using } \\
\text { Contraception } \\
\text { Not Using }\end{array}$ & 398 & 39,7 & 605 & 60,3 & 1003 & 100 & & \\
\begin{tabular}{c} 
Contraception \\
\hline
\end{tabular} & 472 & 53,2 & 416 & 46,8 & 888 & 100 & & \\
\hline
\end{tabular}

The table above shows that as many as 605 people (60.3\%) WUS (Women of Childbearing Age) used contraception and did not give exclusive breastfeeding to their babies. Meanwhile, as many as 398 people (39.7\%) WUS (Women of Childbearing Age) used contraception and gave exclusive breastfeeding to their babies. In addition, the table above shows the results of the OR (Odds Ratio) calculation; it is known that the OR value is 0.58 . Thus, it can say that women of childbearing age (WUS) who use contraception tend to give exclusive breastfeeding to their babies by 0.58 times greater than those who do not use contraception. Meanwhile, the results of the Chi-Square analysis can be seen that the p-value of the research results is $0.000(\mathrm{p}<0.05)$. Thus, it can be interpreted that there is a correlation between contraceptive use and exclusive breastfeeding in Indonesia.

\section{Discussion}

\section{Contraceptive Use in Indonesia in 2017}

Several factors can influence contraceptive use. Factors that can affect the use of contraception are age, number of children or parity, religion, and lack of public knowledge. The first factor is age; the older a person is, the more a person's desire to not get pregnant again increases.[34] The second factor is the number of children or parity; the number of children in each family must be considered because the more children, the greater life needs. The more frequent childbirth will make the mother's health more vulnerable.[6] The third factor is religion; some religions oppose contraception and argue that contraception is against God's will.[29] Redang et al. (2019) stated that one of the reasons why couples of childbearing age (PUS) did not use contraception was religious regulations.[24] The last factor is public knowledge; lack of knowledge about contraception causes a person not to use contraception.[2]

Based on the statement above, it can conclude that the factors that can influence a person in using or not using contraception include a person's age, number of children, religion, and public knowledge.

\section{Exclusive Breastfeeding in Indonesia in 2017}

Several factors can affect exclusive breastfeeding: mother's knowledge, mother's psychology, mother's education, use of contraception/KB, maternal breast anatomy, support from husband, and support from health workers. A mother's knowledge is the first factor that can affect exclusive breastfeeding for babies. Septiani et al. (2017) stated that mothers with good knowledge could provide exclusive breastfeeding compared to mothers with sufficient knowledge.[28] The second factor is maternal psychology; maternal psychological conditions such as peace of mind and mind affect the adequacy and smoothness of breastfeeding.[7];[23] The third factor is education, a mother's education can affect exclusive breastfeeding. Nasution et al. (2016) stated that mothers with low education tend not to give exclusive breastfeeding to their babies, compared to mothers with higher education.[19]

The fourth factor, namely the use of contraception, Bingan (2019) and Yuliasari (2015) stated a correlation between contraceptive use and a decrease in the volume and duration of breast milk which affected the adequacy of exclusive breastfeeding.[3];[36] The fifth factor was the anatomy of the mother's breast. The number of lobes, anatomical papillae, or nipples of the mother's breast can affect milk production, making exclusive breastfeeding inhibition.[17] Thus, mothers should breastfeed their babies 
as often as possible to avoid breast engorgement.[23] The sixth factor is support from husbands. Nasution et al. (2016) revealed that mothers with husband support are less likely to give non-exclusive breastfeeding to their babies than mothers who receive support from their husbands.[19] The last factor is support from health workers. Sadiman et al. (2014) stated that the support of health workers to breastfeeding mothers significantly affects exclusive breastfeeding to infants.[27]

Based on these statements, it can conclude that exclusive breastfeeding can be influenced by several factors, including knowledge, psychological condition, mother's education, contraceptive use, maternal breast anatomy, support from husbands, and support from health workers to mothers. Some of these factors can affect the adequacy and smoothness of breast milk.

\section{Correlation Between Contraceptive Use and Exclusive Breastfeeding in Indonesia in 2017}

This research is in line with other research conducted by Dewi (2019); namely, there is a correlation between the use of contraception and the smooth production of breast milk.[4] Results of this study are also in line with other studies which state that there is a correlation between the use of contraceptives and milk production.[21] Permatasari (2018) states a correlation between the use of hormonal contraception and milk production in breastfeeding mothers.[20] The use of contraception is related to the smooth production of breast milk. Contraceptives such as IUDs and natural family planning methods will not interfere with breast milk production. Meanwhile, contraception such as injections, pills, and implants can cause milk production to be not smooth.[4]

Inappropriate use of contraception can lead to a lack of milk supply and the baby not getting enough milk. As many as $80 \%$ of respondents who use inappropriate contraceptives have the adequacy of breast milk, which is not enough.[23] Inappropriate use of contraception includes the use of combined contraceptives containing estrogen and progestin, which can cause a decrease in the duration and volume of breast milk.[15] Estrogen levels can suppress FSH so that it stimulates the anterior pituitary lobe to secrete a luteinizing hormone, which causes the hypothalamus to release dopamine, a prolactin inhibitory factor. Dopamine can cause the breasts to not produce milk because dopamine decreases prolactin secretion by up to ten times.[22] If the contraceptive only contains the hormone progestin, then the user will not affect the duration or volume of breast milk. Mothers who use combination contraception have a shorter duration of breastfeeding compared to non-hormonal contraception.[18]

Based on some studies above, it can be concluded that there is a correlation between the use of contraception and exclusive breastfeeding. Many WUS (Women of Childbearing Age) in this study used contraception but did not give exclusive breastfeeding to their babies. Non-Exclusive breastfeeding can be caused by improper use of contraception. Inappropriate use of contraception can cause breastfeeding to be not smooth. Contraceptives that can cause breastfeeding are not smooth, namely contraception in which there are the hormones estrogen and progestin. Examples of contraception include pills, injections, and implants. Meanwhile, women of childbearing age (WUS) who can provide exclusive breastfeeding to their babies use contraception that does not contain estrogen and progestin, such as the IUD or natural family planning.

\section{CONCLUSION AND FURTHER RESEARCH Conclusion}

Based on the study results, it can be concluded that there is a correlation between contraceptive use and exclusive breastfeeding in Indonesia in 2017. 


\section{Suggestion}

For the Community

The results of this study can be used as information and recommendations for the community in the use of contraception during exclusive breastfeeding for infants aged 0 to 6 months. Mothers who are breastfeeding should use contraception that does not contain estrogen and progestin, such as IUDs and natural family planning. Breastfeeding mothers should avoid contraception containing estrogen and progestin such as pills, injections, and implants; these contraceptives cannot cause breast milk to become uneven.

\section{For the Government}

The government is expected to be able to provide information to the public about contraception. That can cause breastfeeding to be not smooth and which does not cause breastfeeding to be not smooth for the community, especially WUS (Women of childbearing age) who are giving exclusive breastfeeding to infants aged 0 to 6 months. Can convey information by distributing leaflets about contraception that breastfeeding mothers cannot use and distributed by every Posyandu cadre through the WhatsApp application.

\section{For Further Researchers}

This research can be used as a reference or reference for further researchers in continuing this research using other variables not examined by the researchers in this study.

\section{Limitation}

The limitation of this research is that the data used is secondary data contained in the 2017 IDHS. If there are other factors, it cannot be measured.

\section{REFERENCES}

[1] Aridiyah, F. O., Rohmawati, N., \& Ririanty, M. (2015). Faktor-Faktor yang Mempengaruhi Kejadian Stunting pada Anak Balita di Wilayah Pedesaan dan Perkotaan (The Factors Affecting Stunting on Toddlers in Rural and Urban Areas). E-Jurnal Pustaka Kesehatan, 3(1).

[2] Arum, D., \& Sujiyatini, S. (2017). Panduan Lengkap Pelayanan KB Terkini. Nuha Medika.

[3] Bingan, E. C. S. (2019). Pemakaian KB Suntik 3 Bulan dengan Kecukupan ASI Eksklusif pada Ibu yang Mempunyai Anak Usia 7-23 Bulan. Jurnal Ilmiah Bidan, 6(2).

[4] Dewi, A. D. C. (2019). Faktor-Faktor Yang Mempengaruhi Kelancaran Produksi ASI. Jurnal 'Aisyiyah Medika, 4(1), 22-34.

[5] Erlani, N. K. A. T., Seriani, L., \& Ariastuti, L. P. (2020). Perilaku Pemberian ASI Eksklusif Pada Wanita Pekerja Tenaga Kesehatan Rumah Sakit Umum Pusat Sanglah. Jurnal Medika Udayana, 9(6), 70-78.

[6] Hartanto, H. (2013). Keluarga Berencana dan Kontrasepsi. Pustaka Sinar Harapan.

[7] Kamariyah, N. (2014). Kondisi Psikologi Mempengaruhi Produksi Asi Ibu Menyusui di BPS Aski Pakis Sido Kumpul Surabaya. Jurnal Ilmiah Kesehatan, 7(12), 29-36.

[8] Kementerian, K. R. (2014). Infodatin: Situasi dan Analisis Asi Eksklusif. https://pusdatin.kemkes.go.id/download.php?file=download/pusdatin/infodatin/infodati n-asi.pdf

[9] Kementerian Kesehatan RI. (2016). Profil Kesehatan Indonesia 2015.

[10] Kementerian Kesehatan RI. (2017). Profil Kesehatan Indonesia Tahun 2016.

[11] Kementerian Kesehatan RI. (2018). Profil Kesehatan Indonesia Tahun 2017. 
[12] Kementerian Kesehatan RI. (2019). Profil Kesehatan Indonesia Tahun 2018.

[13] Kementerian, K. R. (2020a). Profil Kesehatan Indonesia Tahun 2019.

[14] Kementerian, K. R. (2020b). Rencana Strategis Kementerian Kesehatan Tahun 2020-2024.

[15] Khamzah, S. N. (2012). Segudang Keajaiban ASI yang Harus Anda Ketahui. Flashbooks.

[16] Lake, A. (2012). Healthy Baby, Healthy Planet. UNICEF.

[17] Marmi. (2012). Asuan Kebidanan Pada Masa Nifas "Peurperium Care." Pustaka Pelajar.

[18] Montolalu, A., Wilopo, S. A., \& Prawitasari, S. (2013). Pengaruh Kontrasepsi Hormonal Dan Non Hormonal Terhadap Lamanya Menyusui Di Indonesia (Analisis Data Sdki Tahun 2007). Jurnal Ilmiah Bidan, 1(1), 1-15.

[19] Nasution, S. I., Liputo, N. I., \& Mahdawaty. (2016). Faktor-Faktor yang Berhubungan dengan Pola Pemberian ASI Eksklusif di Wilayah Kerja Puskesmas Bungus Tahun 2014. Jurnal Kesehatan Andalas, 5(3), 635-639.

[20] Permatasari, D. (2018). Hubungan Antara Penggunaan Kontrasepsi Hormonal Dengan Produksi ASI Pada Ibu Menyusui di BPS Tatik S, Desa Ngasem, Kecamatan Ngasem, Kabupaten Kediri. Jurnal Ilmu Kesehatan, 3(2), 80-84.

[21] Pranajaya, R., \& Rudiyanti, N. (2013). Determinan Produksi ASI Pada Ibu Menyusui. Jurnal Keperawatan, 9(2), 227-237.

[22] Purwaningsih, E., \& Wati, R. S. (2011). Pengaruh Kontrasepsi Suntik Terhadap Pengeluaran ASI eksklusif di BPS Triparyati Kemalang Kabupaten Klaten. Jurnal Involusi Kebidanan, 1(1), 9-19.

[23] Rayhana, \& Sufriani. (2017). Faktor-Faktor yang Mempengaruhi Produksi ASI Dengan Kecukupan ASI. In Jurnal Ilmiah Mahasiswa Fakultas Keperawatan (Vol. 2, Issue 3).

[24] Redang, T. A., Dion, Y., \& Nahak, M. (2019). Gambaran Faktor- Faktor Penyebab Ketidakikutsertaan Pasangan Usia Subur Dalam Memilih Alat Kontrasepsi Mantap Di Puskesmas Kaubele Kabupaten Timor Tengah Utara. CHMK Midwifery Scientific Journal, 2(3), 71-76.

[25] Roesli. (2013). Mengenal ASI Eksklusif. Trubus Agriwidya.

[26] Rofikoh, Widiastuti, Y. P., \& Istioningsih. (2019). Gambaran Tingkat Pegetahuan Pasangan Usia Subur Tentang Kontrasepsi Hormonal dan Non Hormonal. Jurnal Ilmiah Permas: Jurnal Ilmiah STIKES Kendal, 9(3), 197-206. 